\title{
Analisis Kesalahan dalam Menyelesaikan Soal Geometri Siswa Kelas XI SMK Bina Warga Lemahabang
}

\author{
Misni, Ferry Ferdianto \\ Program Studi Pendidikan Matematika, Universitas Swadaya Gunung Jati Cirebon, \\ Jl. Perjuangan No. 01 Kampus II Unswagati Cirebon, Indonesia \\ Korespondensi; Misni, Email: misni_09@yahoo.com; Ferry Ferdianto,Email: ferryunswagati@gmail.com
}

\begin{abstract}
Abstrak
Geometri mengandung gambar dan simbol-simbol yang abstrak sehingga butuh penalaran yang tinggi. Kebanyakan siswa kurang memahami materi geometri, sehingga ketika siswa dihadapkan dengan soal geometri akan terjadi kesalahan dalam pengerjaannya. Oleh karena itu, perlu adanya identifikasi dari kesalahan-kesalahan siswa dalam menjawab soal-soal geometri. Adapun, tujuan dari penelitian ini adalah untuk mengetahui jenis-jenis kesalahan siswa dalam menyelesaikan soal geometri dan untuk mengetahui faktor-faktor yang menjadi kesalahan siswa dalam menjawab soal geomerti. Penelitian ini menggunakan metode deskriptif kualitatif. Sampel yang digunakan dalam penelitian ini adalah siswa kelas XI AK SMK Bina Warga Lemahabang. Pengambilan sampelnya yaitu dengan teknik purposive sampling berdasarkan hasil tes siswa. Cara dalam menganalisis hasil tes siswa dilakukan dengan mengidentifikasi data yang diperoleh dari hasil tes siswa lalu disimpulkan jenisjenis kesalahannya. Adapun hasil analisis soal dan jawaban siswa, diketahui bahwa faktor-faktor yang menyebabkan kesalahan adalah (1) kesalahan dalam memahami konsep (2) kurangnya tingkat penalaran siswa untuk mencapai sebuah ruang. (3) kurang teliti (4) kurang menguasai materi (5) kesalahan dalam menuliskan formula.
\end{abstract}

Kata Kunci: Analisis kesalahan; Faktor kesalahan; Geometri

\begin{abstract}
Geometry contains abstract images and symbols so it needs high reasoning. Most students do not understand geometry material, so that when students are faced with geometric problems there will be errors in the process. Therefore, it is necessary to identify students' mistakes in answering geometry questions. Meanwhile, the purpose of this study is to determine the types of student errors in solving geometry problems and to find out the factors that are the students' mistakes in answering geomechanical questions. This study used descriptive qualitative method. The sample used in this study was class XI AK SMK Bina Warga Lemahabang. Sampling is by purposive sampling technique based on student test results. The way to analyze student test results is done by identifying data obtained from student test results and then concluding the types of errors. The results of the analysis of the questions and answers of students, it is known that the factors that cause errors are (1) errors in understanding the concept (2) the lack of students' level of reasoning to reach a space. (3) inaccurate (4) lack of mastery of material (5) errors in writing formula.
\end{abstract}

Keywords: Error analysis; Error factor; Geometry

\section{Pendahuluan}

Mata pelajaran matematika adalah sebagai dasar ilmu untuk pelajaran-pelajaran lainnya. Oleh karena itu siswa dibekali dengan pengetahuan matematika, sehingga siswa dapat berpikir logis, kritis, kreatif, analisis, sistematis, dan dapat menyelesaikan permasalahan. Sependapat dengan hal tersebut Soejadi mengemukakan beberapa definisi matematika (Soejadi, 2000), yaitu: (1) Matematika adalah cabang pengetahuan eksak dan terorganisasi secara sistematis (2) Matematika adalah pengetahuan tentang bilangan dan kalkulasi (3) Matematika adalah pengetahuan tentang penalaran logis dan berhubungan dengan bilangan. (4) Matematika adalah pengetahuan tentang fakta-fakta kuantitatif dan masalah ruang dan bentuk. (5) Matematika adalah pengetahuan tentang struktur-struktur yang logis. (6) Matematika adalah pengetahuan tentang aturan yang ketat. Serta matematika dapat diaplikasikan dalam kehidupan sehari-hari agar siswa dapat memperoleh, menganalisis, dan memanfaatkan informasi yang didapatnya 
dengan baik dan benar. Dan siswa dapat dengan mudah menyelesaikan permasalahan hidupnya, karena sudah terbiasa menyelesaikan permasalahan dalam soal matematika. Hal tersebut sejalan dengan yang dikemukakan oleh Paling (Mulyono, 2012) bahwa matematika adalah suatu cara untuk menemukan jawaban terhadap masalah yang dihadapi manusia, menggunakan informasi, menggunakan pengetahuan tentang bentuk dan ukuran, menggunakan pengetahuan tentang menghitung dan yang paling penting adalahmemikirkan dalam diri manusia itu sendiri dalam melihat dan menggunakan hunbungan-hubungan .

Namun kebanyakan siswa menganggap matematika adalah pelajaran yang sulit, karena matematika yang bersifat abstrak dan butuh penalaran yang tinggi untuk memahaminya. Salah satunya dalam pelajaran geometri yang mengandung gambar-gambar dan simbol-simbol, siswa dituntut untuk memiliki kemampuan visual spasial yang baik agar dapat menyelesaikan permasalahan-permasalahan dalam materi geometri. Menurut Susanta (1991:3) berpendapat bahwa belajar geometri adalah bernalar, mengaitkan simbol-simbol, menghubungkan struktur-struktur untuk mendapatkan suatu pengertian dan mengaplikasikan konsep-konsep tersebut dalam situasi nyata. Sejalan dengan hal tersebut Soemadi (1991:1) berpendapat bahwa manfaat pelajaran geometri di Sekolah Menengah Atas meliputi bekal untuk melanjutkan pendidikan bagi yang memenuhi persyaratan, manfaat sebagai bekal dalam kehidupan sehari-hari, serta manfaat sebagai bekal untuk memasuki dunia kerja. Ketiga manfaat tersebut mengandung aspek formal dan material.

Rendahnya kemampuan siswa pada materi geometri bisa dilihat dari tingkat pemahaman siswa. Salah satunya bisa dilihat dari hasil jawaban siswa dalam menjawab soal-soal geometri. Dengan menganalisis jawaban siswa akan diketahui kesalahan-kesalahan siswa dalam menjawab soal-soal tersebut, sehingga dapat di simpulkan seberapa pahamya siswa pada materi tersebut. Tingkat kesulitan siswa dalam memahami materi geometri ada pada penalarannya. Namun penalaran siswa yang rendah dapat menghasilkan hasil belajar siswa menjadi rendah pula. Menurut Sudarman (2000:3) menyatakan bahwa diantara berbagai cabang matematika, pemahaman terhadap geometri menempati posisi yang paling memprihatinkan, yaitu paling rendah prestasi hasil belajarnya. Sependapat dengan hal tersebut Madja (2002:3) menyatakan bahwa hasil tes geometri masih kurang memuaskan (lebih rendah) jika dibandingkan dengan hasil tes materi matematika yang lain.

Soal-soal geometri mengandung gambar dan simbol-simbol yang abstrak sehingga butuh penalaran yang tinggi siswa untuk menyelesaikan permasalahan dalam soal geometri. Tingkat penalaran siswa dalam menjawab soal geometri sangatlah rendah. Sehingga siswa kurang memahami dalam mengaplikasikan konsepnya, dan kurang tepat dalam penulisan rumus untuk menyelesaikan soal tersebut. Sehingga dapat memicu tingkat ketelitian siswa dalam menjawab soal. Sejalan dengan hal tersebut Titi Solfitri dan Yenita Roza menyatakan bahwa kesalahan-kesalahan yang dilakukan oleh siswa dalam menyelesaikan soal-soal, salah satunya yaitu corelles error yang disebut juga sebagai kesalahan kecerobohan atau kurang cermat. Kesalahan dalam proses penyelesaian sering dijumpai dalam menyelesaikan soal matematika, dan dalam penelitian kesalahan yang diamati fokusnya kepada kesalahan tentang konsep, prosedur, dan kesalahan operasi atau kecerobohan.

Dengan memberikan tes atau soal-soal tentang geometri akan terlihat penguasaan siswa terhadap materi yang sudah dipelajari. Kesalahan yang dilakukan siswa dalam menjawab soal akan menjadi bahan untuk mengetahui sejauh mana pemahaman siswa pada materi tersebut. Oleh karena itu, perlu adanya identifikasi dari kesalahan-kesalahan siswa dalam menjawab soal-soal geometri dan mencari tahu faktor-faktor apa saja yang mempengaruhi kesalahan-kesalahan siswa dalam menjawab soal-soal geometri. Adapun, tujuan dari penelitian ini adalah untuk mengetahui jenis-jenis kesalahan siswa kelas XI SMK Bina Warga Lemahabang dalam menyelesaikan soal-soal geometri dan untuk mengetahui faktor apa saja yang menjadi kesalahan siswa dalam menjawab soal-soal geomerti.

Kesalahan-kesalahan yang dilakukan siswa dalam menjawab soal-soal dikemukakan menurut Nana Sudjana, yang mengatakan bahwa kesalahan-kesalahan yang dilakukan siswa dalam mengerjakan soalsoal matematika dapat diidentifikasikan menjadi beberapa aspek, seperti bahasa, imajinasi, prasyarat, tanggapan dan terapan. (1) Aspek bahasa merupakan kesulitan dan kekeliruan siswa dalam menafsirkan kata-kata atau simbol-simbol dan bahasa yang digunakan dalam matematika. (2) Aspek imajinasi merupakan kesulitan dan kekeliruan siswa dalam imajinasi (spasial) dalam dimensi-dimensi tiga yang berakibat salah dalam mengerjakan soal-soal matematika. (3) Aspek prasyarat merupakan kesalahan dan kekeliruan siswa dalam mengerjakan soal matematika karena bahan pelajaran yang sedang dipelajari siswa belum dikuasai. (4) Aspek tanggapan merupakan kekeliruan dalam penafsiran atau 
tanggapan siswa terhadap konsepsi, rumus-rumus, dan dalil-dalil matematika dalam mengerjakan soal matematika. (5) Aspek terapan merupakan kekeliruan siswa dalam menerapkan rumus-rumus dan dalildalil matematika dalam mengerjakan soal matematika.

Dalam bidang geometri, Kesalahan siswa yang dilakukan adalah kesalahan konsep dan kesalahan hitung. Berdasarkan latar belakang tersebut penulis berusaha untuk mengidentifikasi kesalahankesalahan yang dilakukan oleh siswa dalam menyelesaikan soal- soal tentang materi bangun ruang sisi datar dan memberikan alternatif untuk permasalahan tersebut. Dengan adanya soulusi yang diberikan, diharapkan dapat meminimalisisr kesalahan-kesalahan tersebut (Yunia, 2004).

\section{Metode}

Penelitian ini merupakan penelitian deskriptif kualitatif. Menurut Sugiyono (2013: 13) metode penelitian kuantitatif dapat diartikan sebagai metode penelitian yang berlandaskan pada filsafat positivisme, digunakan untuk meneliti pada populasi atau sampel tertentu, teknik pengambilan sampel pada umumnya dilakukan secara random, pengumpulan data menggunakan instrumen penelitian, analisis data bersifat kuantitatif/ statistik dengan tujuan untuk menguji hipotesis yang telah ditetapkan. Sampel dalam penelitian ini adalah siswa kelas XI AK dari sekolah SMK Bina Warga Lemahabang yang diambil secara acak satu kelas dari seluruh siswa kelas XI. Pengambilan sampelnya yaitu dengan teknik purposive sampling berdasarkan hasil tes siswa.

Pengumpul data yang digunakan dalam penelitian ini adalah dengan tes tertulis. Menurut Suharsimi (2012:46) tes adalah serentetan pertanyaan atau latihan serta alat lain yang digunakan untuk mengukur keterampilan, pengetahuan intelegensi, kemampuan atau bakat yang dimiliki oleh individu atau kelompok. Instrumen yang digunakan dalam penelitian ini adalah tes pemahaman konsep dalam bentuk essay yang terdiri dari 3 butir soal. Data ini digunakan untuk menganalisis jenis-jenis kesalahan siswa dalam menyelesaikan soal geometri.

Menurut Miles dan Huberman (1992: 16) analisis terdiri dari tiga alur kegiatan yang terjadi secara bersamaan yaitu: reduksi data, penyajian data penarikan kesimpulan atau verifikasi. Mengenai tiga alur tersebut secara lebih lengkapnya yaitu pada langkah-langkah berikut: (1) Reduksi data yaitu pemilihan atau pengumpulan data dari hasil tes siswa. Kemudian dari data tersebut diperiksa dan dianalisis kesalahan-kesalahn siswa dalam menyelesaikan soal tes tersebut. (2) Penyajian data yaitu, menganalisis data yang diperoleh. Dari kesalahan-kelasahan siswa dalam menyelesaikan soal dianalisis sehingga akan ditemukan faktor-faktor penyebab kesalah siswa dalam menyelesaikan soal. (3) Penarikan kesimpulan yaitu, dari semua data yang diperoleh dan telah di analisis sehingga telah ditemukan sebuah kesimpulan data yang telah dikumpulkan.

\section{Hasil dan Bahasan}

Tabel 1. Presentase Kesalahan Siswa.

\begin{tabular}{|c|c|c|c|}
\hline $\begin{array}{l}\text { Nomer } \\
\text { Soal }\end{array}$ & $\begin{array}{l}\text { Jumlah Siswa yang } \\
\text { Menjawab Salah }\end{array}$ & $\begin{array}{l}\text { Presentase } \\
(\%)\end{array}$ & Keterangan \\
\hline \multirow{5}{*}{1} & a. 2 siswa & $10 \%$ & Kesalahan dalam menyelesaikan proses perhitungannya. \\
\hline & b. 5 siswa & $25 \%$ & Kurang memahami soal yang akan diselesaikan. \\
\hline & c. 19 siswa & $95 \%$ & $\begin{array}{l}\text { Siswa tidak bisa membayangkan ruang kubus, sehingga penulisan } \\
\text { rumusnya kurang tepat. }\end{array}$ \\
\hline & d. 14 siswa & $70 \%$ & Kurang teliti. \\
\hline & e. 19 siswa & $95 \%$ & $\begin{array}{l}\text { Siswa kurang dalam bernalarnya, sehingga kurang tepat dalam } \\
\text { menjawabnya. }\end{array}$ \\
\hline \multirow{3}{*}{2} & a. 4 siswa & $20 \%$ & Salah dalam penulisan rumus. \\
\hline & b. 18 siswa & $90 \%$ & $\begin{array}{l}\text { Belum paham konsep dan kurang tepat dalam mensubtitusikan } \\
\text { nilai. }\end{array}$ \\
\hline & c. 18 siswa & $90 \%$ & Salah dalam menentukan perbandingan rumusnya. \\
\hline \multirow[b]{2}{*}{3} & a. 7 siswa & $35 \%$ & Kurang paham proses penyelesaiannya \\
\hline & b. 20 siswa & $100 \%$ & $\begin{array}{l}\text { Siswa kurang paham konsep, dan ada } 8 \text { siswa yang tidak } \\
\text { menjawab soal. }\end{array}$ \\
\hline
\end{tabular}


Diuraikan secara garis besar hasil temuan kesalahan yang dilakukan peserta didik dalam menyelesaikan soal geometri seperti tabel 1.

Berdasarkan tabel 1 Dapat disimpulkan beberapa kesalahan siswa dalam menyelesaikan soal-soal geometri. Pada soal nomor 1 terdapat siswa yang salah dalam menjawab soal. Bentuk kesalahan yang dilakukan siswa adalah kesalahan konseptual, yaitu kesalahan dalam memahami gagasan abstrak. Sehingga dalam penulisan rumusnya juga salah.

1. Diketahui kubus $\mathrm{ABCD}$ EFGH memiliki panjang rusuk $8 \mathrm{~cm}$. Tentukan : a. Jarak titik E ke D

b. Jarak titik $\mathrm{H}$ ke B

c. Jarak titik C ke garis AH

d. Jarak titik B ke bidang ACGE

e. Jarak garis HG ke bidang ABFE

Gambar 1. Soal yang diujikan.

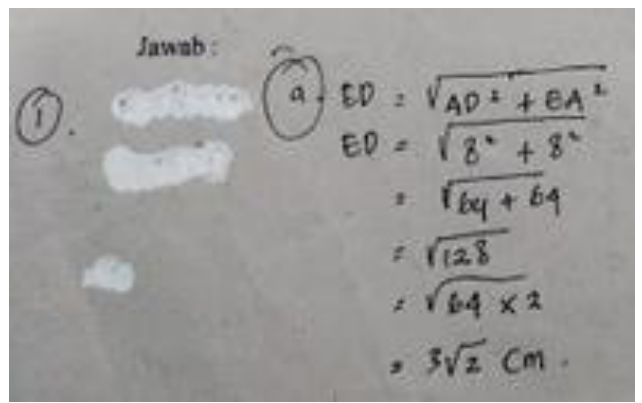

Gambar 2. Jawaban siswa.

Pada soal no 1 bagian (a) dari 20 siswa yang melakukan kesalahan dalam menyelesaikan soal ada 2 siswa yang memiliki presentase kesalahan sebanyak 10\% dari jumlah keseluruhan data. Pada gambar 2, kesalahan yang tampak pada penyelesain soal ini karena siswa kurang paham dalam menyelesaikan proses perhitungannya, sehingga hasil akhir dari jawaban siswa tersebut kurang tepat.

Gambar 3. Jawaban siswa.

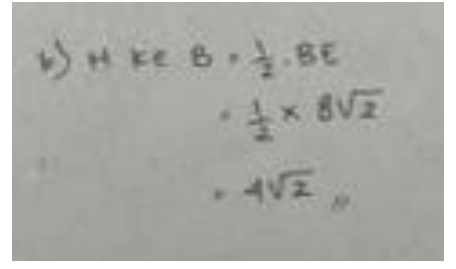

Pada soal no 1 bagian (b) dari 20 siswa yang melakukan kesalahan dalam menyelesaikan soal ada 5 siswa yang memiliki presentase kesalahan sebanyak $25 \%$ dari jumlah keseluruhan data. Pada jawaban soal nomor 1 bagian (b) pada gambar 3, sisw salah dalam memahami soal. Sehingga siswa salah dalam menuliskan rumus dan hasil akhir yang kurang tepat.

Berdasarkan penelitian Cahyono (2017) menunjukkan bahwa kesalahan keterampilan proses yang dilakukan siswa disebabkan karena:

a) Kurangnya ketelitian siswa dalam melakukan operasi hitung bilangan yang berada di bawah tanda akar;

b) Kemampuan siswa yang rendah dalam melakukan perhitungan dan menentukan langkah yang harus dilakukan.

Gambar 4. Jawaban siswa.

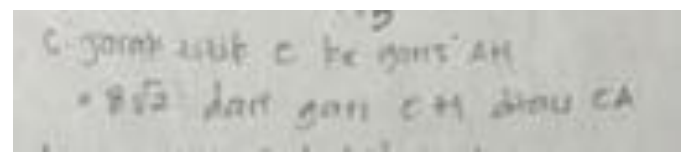

Pada soal no 1 bagian (c) dari 20 siswa yang melakukan kesalahan dalam menyelesaikan soal ada 19 siswa yang memiliki presentase kesalahan sebanyak 95\% dari jumlah keseluruhan data. Pada 
jawaban soal nomor 1 bagian (c) pada gambar 4, siswa melakukan kesalahan konsep, yaitu siswa salah dalam menentukan rumus untuk menjawab permasalahan yang diberikan. Kesalahan tersebut timbul karena kurang penalaran siswa dalam membayangkan suaru ruang kubus. Sehingga siswa kurang tepat dalam menentukan rumus dan hasil akhirnya pun kurang tepat.

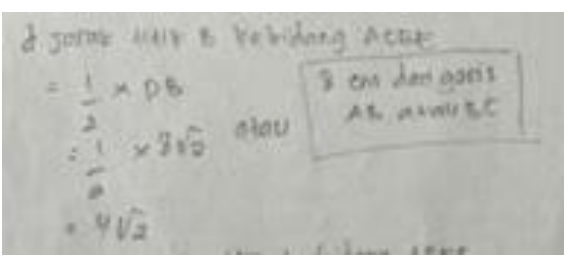

Gambar 5. Jawaban siswa.

Pada soal no 1 bagian (d) dari 20 siswa yang melakukan kesalahan dalam menyelesaikan soal ada 14 siswa yang memiliki presentase kesalahan sebanyak $70 \%$ dari jumlah keseluruhan data Pada jawaban soal nomor 1 bagian (d) pada gambar 5, kurangnya pemahaman siswa pada soal ini dan kurang teliti. Sehingga hasil akhir dari jawaban siswa kurang tepat.

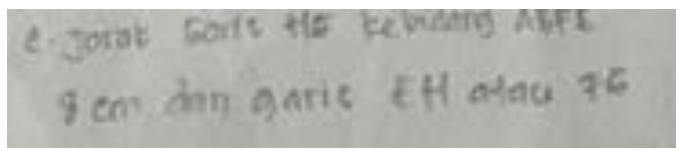

Gambar 6. Jawaban siswa.

Pada soal no 1 bagian (e) dari 20 siswa yang melakukan kesalahan dalam menyelesaikan soal ada 19 siswa yang memiliki presentase kesalahan sebanyak 95\% dari jumlah keseluruhan data. Pada jawaban soal nomor 1 bagian (e), Siswa kurang memahami konsepnya dan kurang dalam bernalarnya, sehingga kurang tepat dalam menyelesaikan soalnya.

Gambar 7. Soal yang diujikan.
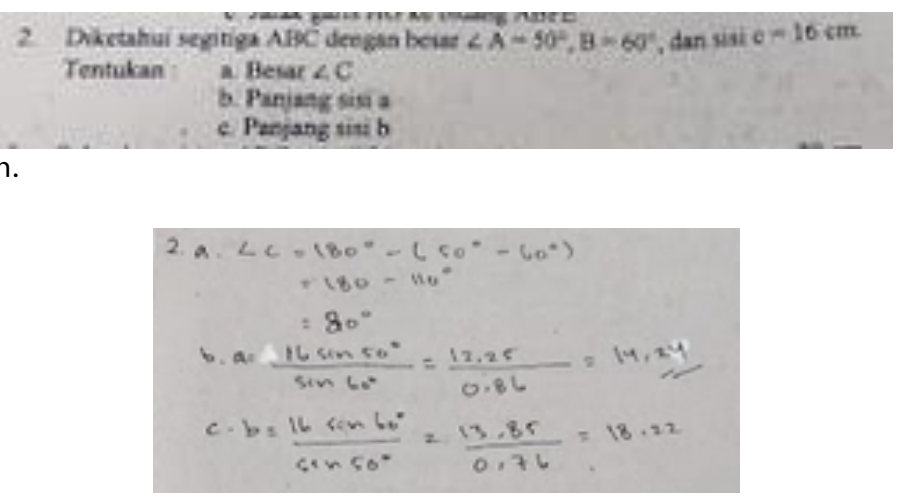

Gambar 8. Jawaban siswa.

Pada soal nomor 2 kebanyakan siswa salah dalam menentukan rumus yang akan digunakan untu menyelesaikan masalah dalam soal tersebut. Siswa mengetahui dan hapal dengan rumusnya, akan tetapi salah dalam membandingkan antara dua perbandingan. Pada soal no 2 bagian (a) dari 20 siswa yang melakukan kesalahan dalam menyelesaikan soal ada 4 siswa yang memiliki presentase kesalahan sebanyak $20 \%$ dari jumlah keseluruhan data. Jawaban soal nomor 2 bagian (a), siswa salah dalam menuliskan rumus dan terdapat siswa yang sudah tahu rumusnya tetapi prosesnya masih salah.

Pada soal no 2 bagian (b) dari 20 siswa yang melakukan kesalahan dalam menyelesaikan soal ada 18 siswa yang memiliki presentase kesalahan sebanyak 90\% dari jumlah keseluruhan data. Jawaban nomor 2 bagian (b), siswa salah dalam substitusikan nilai.

Pada soal no 2 bagian (c) dari 20 siswa yang melakukan kesalahan dalam menyelesaikan soal ada 4 siswa yang memiliki presentase kesalahan sebanyak $20 \%$ dari jumlah keseluruhan data. Jawaban nomor 2 bagian (c) siswa telah tepat menentukan rumus untuk menjawab persoalan, namun kesalahan yang dilakukan siswa disebabkan oleh kesalahan pada jawaban soal yang diperoleh sebelumnya. 
Gambar 9. Soal yang diujikan.

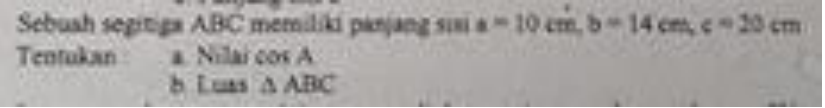

Gambar 9. So

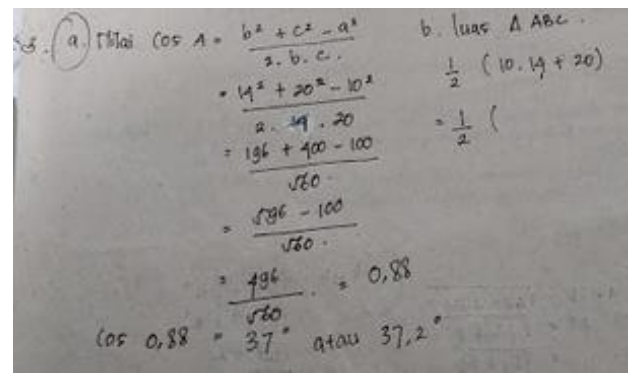

Gambar 10. Jawaban siswa.

Pada soal nomor 3 terdapat siswa yang keliru dalam melakukan proses penyelesaian soal sehingg jawaban siswa kurang tepat. Karena kurangnya pemahaman proses penjumlahannya.

Pada soal no 3 bagian (a) dari 20 siswa yang melakukan kesalahan dalam menyelesaikan soal ada 7 siswa yang memiliki presentase kesalahan sebanyak 35\% dari jumlah keseluruhan data. Jawaban soal nomor 3 bagian (a), siswa sudah mengetahui rumus dalam menyelesaikan soal tersebut, tetapi kesalahannya ada pada proses penghitungannya. Pada soal no 2 bagian (a) dari 20 siswa yang melakukan kesalahan dalam menyelesaikan soal ada 4 siswa yang memiliki presentase kesalahan sebanyak 20\% dari jumlah keseluruhan data Jawaban soal nomor 3 bagian (b) siswa kurang memahai konsepnya sehingga dalam penulisan rumusnya kurang tepat.

Jika dilihat dari hasil penelitian secara keseluruhan dapat diketahui bahwa banyak peserta didik melakukan kesalahan konsep dibanding kesalahan lain yaitu prosedur dan ceroboh hal ini disebabkan beberapa hal dari hasil analisis soal dan jawabannya dari beberapa siswa diketahui bahwa faktorfaktor yang menyebabkan kesalahan adalah (1) kesalahan dalam memahami konsep (2) kurangnya tingkat penalaran siswa untuk mencapai sebuah ruang. (3) kurang teliti (4) kurang menguasai materi (5) kesalahan dalam menuliskan formula.

\section{Kesimpulan}

Berdasarkan hasil penelitian dan pembahasan disimpulkan bahwa jenis kesalahan yang dilakukan siswa kelas XI AKL dari sekolah SMK Bina Warga Lemahabang dalam menyelesaikan kesebangunan terdiri dari kesalahan konsep, kesalahan prosedur, dan kesalahan perhitungan. Kesalahan siswa yang dominan muncul dalam menyelesaikan soal-soal tersebut adalah kesalahan konsep. Dari hasil analisis soal dan jawabannya dari beberapa siswa diketahui bahwa faktor-faktor yang menyebabkan kesalahan adalah (1) kesalahan dalam memahami konsep (2) kurangnya tingkat penalaran siswa untuk mencapai sebuah ruang. (3) kurang teliti (4) kurang menguasai materi (5) kesalahan dalam menuliskan formula.

\section{Referensi}

[1] Cahyono, N. Dodi. 2017. Analisis Kesalahan Jawaban Siswa dalam Menyelesaikan Soal Cerita Materi Pecahan Berdasarkan Kategori Kesalahan Newman di SMP Negeri 2 Sawit. Skipsi. Universitas Muhammadiyah Surakarta.

[2] Elizabeth, Angelina Christofania. 2016. Analisis Kesalahan Dalam Menyelesaikan Soal Geometri Ruang Pada Siswa Kelas X Sma Marsudirini Muntilantahun Ajaran 2014/2015.

[3] Intansari, Mira, Dkk. 2018. Desain Penelitian Kuantitatif Deskriptif. Surabaya.

[4] Istiani, Ana Dan Hidayatulloh. 2017. Analisis Kesalahan Siswa Dalam Menyelesaikan Soal Pada Materi Bangun Ruang Sisi Datar. Lampung.

[5] Nurkhasanah, Suwar Dewi. 2016. Nalisis Kesalahan Dalam Penyelesaian Soal Matematika Berbasis Timss Konten Geometri Pada Siswa Kelas Viii Semester Genap Smp Negeri 1 Mojosongo Tahun 2015/2016. Surakarta.

[6] Solfitri, Titi Dan Yenita Roza. 2015. Analisis Kesalahan Dalam Menyelesaikan Soal-Soal Geometri Siswa Kelas Ix Smpn SeKecamatan Tampan Pekanbaru (The Analysis of Error On Solving Geometry Problem of Student at Class Ix Junior High School On Tampan Subdistrict Pekanbaru). Prosiding Semirata 2015 Bidang MIPA BKS-PTN Barat. Hal 295-303.

[7] Sulistiani, Ika Ratih. 2012. Pembelajaran Luas Daerah Persegi Panjang Berdasarkan Standar Pengajaran National Council of Teachers of Mathematics (NCTM) Untuk Meningkatkan Pemahaman Siswa Kelas III SDN Dinoyo I Malang. Jurnal Fourier. Vol. 1, No. 1, $11-16$. 